\title{
Kako je zdravlje povezano sa zaposlenošću u starijoj radnoj dobi u Hrvatskoj?
}

Smolić, Šime; Čipin, Ivan; Međimurec, Petra

Source / Izvornik: Odabrani prijevodi, 2020, 11, 1 - 15

Journal article, Published version

Rad u časopisu, Objavljena verzija rada (izdavačev PDF)

https://doi.org/10.3326/op.52

Permanent link / Trajna poveznica: https:/urn.nsk.hr/urn:nbn:hr:242:205686

Rights / Prava: Attribution-NonCommercial-NoDerivatives 4.0 International/ImenovanjeNekomercijalno-Bez prerada 4.0 međunarodna

Download date / Datum preuzimanja: 2023-04-26

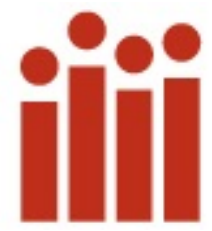

Institute of Public Finance Repository

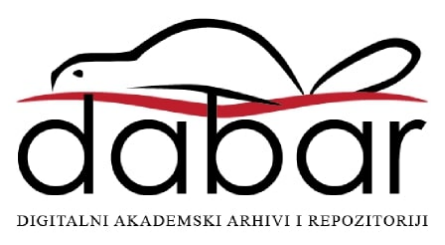




\section{KAKO JE ZDRAVLJE POVEZANO SA ZAPOSLENOŠĆU U STARIJOJ RADNOJ DOBI U HRVATSKOJ?}

DOC. DR. SC. ŠIME SMOLIĆ*

IZV. PROF. DR. SC. IVAN ČIPIN*

DR. sc. PETRA MEĐIMUREC*
ČLANAK ${ }^{* *}$

JEL: I12, J14, J21

DOI: $10.3326 / 0 P .52$

\section{ODABRANI}

\section{PRIJEVODI}

\section{BR. 52}

\section{0.}

ISSN: $1847-7445$

doi: $10.3326 /$ op

\section{citirati:}

Smolić Š, Čipin I. i Međimurec P., 2020. How is health associated with employment during later working life in Croatia? Public Sector

\section{SAŽETAK}

Ovaj rad istražuje kako je samoprocijenjeno zdravlje (self-rated health, SRH), kao pokazatelj općeg zdravlja, povezano sa zaposlenošću tijekom kasnijega radnog vijeka u Hrvatskoj. U radu se na temelju podataka iz šeste runde Istraživanja o zdravlju, starenju i umirovljenju u Europi (the Survey of Health, Ageing and Retirement in Europe, SHARE) procjenjuju modeli logističke regresije s ciljem da se ispita mijenja li se i u kojoj mjeri učinak SRH-a nakon što se u analizu uključe i objektivni zdravstveni pokazatelji. Lošiji SRH smanjuje vjerojatnost za zaposlenost, no ovaj se učinak gubi ako se uvaže i objektivni zdravstveni pokazatelji. To sugerira da su u Hrvatskoj SRH i (kombinirani) objektivni zdravstveni pokazatelji svojevrsni supstituti, pa se u istraživanjima o participaciji na tržištu rada mogu upotrebljavati izmjenično. Budući da rezultati pokazuju da lošije zdravlje smanjuje vjerojatnost za zaposlenost u starijoj radnoj dobi u Hrvatskoj, kako bi se poboljšao radni kapacitet starijeg stanovništva, nositelji javnih politika trebali bi promovirati zdrav život $i$ uvesti učinkovitije javnozdravstvene inicijative.

Ključne riječi: (ne)zaposlenost, zdravlje, starija radna dob, SHARE, Hrvatska

* Ovaj rad koristi se podacima iz SHARE vala 6, vidjeti Börsch-Supan et al. (2013) za metodološke detalje. Prikupljanje podataka u sklopu SHARE-a u najvećoj mjeri financira Europska komisija preko programa FP5 (QLK6-CT-2001-00360), FP6 (SHARE-I3: RII-CT-2006-062193, COMPARE: CIT5-CT-2005-028857, SHARELIFE: CIT4-CT-2006-028812) i FP7 (SHARE-PREP: №211909, SHARE-LEAP: №227822, SHARE M4: №261982). Zahvala njemačkom Ministarstvu obrazovanja i znanosti, Max Planck udruženju za unaprjeđenje znanosti, američkome Nacionalnom institutu za starenje (U01_AG09740-13S2, P01_AG005842, P01_AG08291，P30_AG12815， R21_AG025169，Y1-AG-4553-01， IAG_BSR06-11， OGHA_04-064 HHSN271201300071C) i svim nacionalnim izvorima financiranja na dodatnim sredstvima (vidjeti www.share-project.org za više detalja). Istraživanje je također financirala i Hrvatska zaklada za znanost (projekt IP-01-2018-2497)

** Primljeno: 1. lipnja 2019.

Prihvaćeno: 31. listopada 2019.

\section{Šime SMOLIĆ}

Ekonomski fakultet Sveučilišta u Zagrebu, Trg J. F. Kennedyja 6, 10000 Zagreb e-mail: ssmolic@efzg.hr

ORCiD: 0000-0003-0920-8046

\section{Ivan ČIPIN}

Ekonomski fakultet Sveučilišta u Zagrebu, Trg J. F. Kennedyja 6, 10000 Zagreb

e-mail: icipin@efzg.hr

ORCiD: 0000-0002-5624-0359

\section{Petra MEĐIMUREC}

Ekonomski fakultet Sveučilišta u Zagrebu, Trg J. F. Kennedyja 6, 10000 Zagreb

e-mail: pmedimurec@efzg.hr

ORCiD: 0000-0003-2616-2457 


\section{UvOD}

Trend starenja stanovništva izazvan je dužim očekivanim trajanjem života i dugoročno niskim fertilitetom. Kao i u mnogim drugim zemljama u srednjoj i južnoj Europi, starenje stanovništva u Hrvatskoj ubrzavaju visoke stope emigracije. Hrvatska će prema podatcima Eurostata (2019a.) do sredine stoljeća vjerojatno izgubiti više od $15 \%$ stanovnika. Starenje stanovništva, usporedno s padom ukupnog broja stanovnika, smanjuje raspoloživu radnu snagu i rezultira znatnim nedostatkom radnika u Hrvatskoj (Europska komisija, 2019.). Stoga kretanja starijih radnika na tržištu rada, a osobito odluke o (ranom) umirovljenju (vidjeti Bađun i Smolić, 2018.) postaju važnim, ako ne i središnjim predmetom javne rasprave.

Kako bi ublažili učinke starenja stanovništva i osigurali dovoljno sredstava za isplatu mirovina, nositelji javnih politika aktivno traže načine na koje se radni vijek može produžiti. To, međutim, otvara pitanje mogu li stariji ljudi i dalje raditi s obzirom na svoje zdravstvene i socijalne uvjete. S druge strane, (prerano) umirovljeni koji su tržište rada napustili prije nego li je poželjno, barem s obzirom na svoja zdravstvena i sociodemografska obilježja, mogli bi činiti „neiskorišteni radni kapacitet" (Brugiavini, Croda i Mariuzzo, 2005.).

Stopa zaposlenosti starijih radnika (dob 55 - 64) u Hrvatskoj je 2018. s 42,5\% bila najniža u EU (Eurostat, 2019b.) i nije ispunjavala štokholmski cilj ${ }^{1}$ od 50\% (Europska komisija, 2011.). Stopa zaposlenosti stanovništva (dob 50 - 64) u Hrvatskoj je 2018. s 51,6\% bila (iza Grčke) druga najniža u EU (Eurostat, 2019b.). Tijekom zadnjeg desetljeća, stope zaposlenosti među stanovništvom na kraju radnog vijeka, u dobnim skupinama 50 - 64 i 55 - 64, kretale su se redom oko 50\% i 40\% (Eurostat, 2019b.). To sugerira da u Hrvatskoj radnici s tržišta rada u znatnoj mjeri izlaze prije nego što napune zakonom propisanu dob za odlazak u mirovinu. Istraživanja nude više mogućih razloga, uključujući ekonomsku tranziciju (Tomić, 2014.), nisku kvalitetu radnog života među starijim radnicima (Galić, Parmač Kovačić i Vehovec, 2019.) i institucionalni okvir koji olakšava rano umirovljenje (Baloković, 2011.; Bejaković, 2016.). Međutim, istraživanja u kojima se zaposlenost starijih radnika u Hrvatskoj povezuje s njihovim zdravljem još su uvijek malobrojna, a postojeća literatura o povezanosti zdravlja i zaposlenosti (Bubaš, Miloš i Delić-Brkljačić, 2008.; Ecimović Nemarnik i Macan, 2018.) uglavnom je usmjerena na učinke profesionalnih oboljenja, dok se pitanju starijih radnika općenito pridaje malo pažnje među nositeljima javnih politika (Goić, 2017.). Dakle, povezanost općeg zdravlja sa zaposlenošću tijekom starije radne dobi u Hrvatskoj tek je potrebno detaljnije istražiti.

$\mathrm{S}$ tom se namjerom u ovom radu upotrebljavaju podatci iz Istraživanja o zdravlju, starenju i umirovljenju u Europi (the Survey of Health, Ageing and Retirement in Europe, SHARE). Glavni je cilj istražiti kako je samoprocijenjeno zdravlje (self-rated health, SRH), kao pokazatelj općeg zdravlja, povezano sa zaposlenošću tijekom kasnijega radnog vijeka (dob 50 - 64) u Hrvatskoj. Neka dosadašnja istraživanja, SRH uključuju kao jedinu zdravstvenu varijablu povezanu s participacijom starijih radnika na tržištu rada u Hrvatskoj (Ostrovidov Jakšić i Jakšić, 2019.), no problem je s takvim pristupom to što SRH može biti endogen s obzirom na participaciju na tržištu rada. Primjerice, ljudi mogu loš(ij)e ocijeniti vlastito zdravlje da bi opravdali svoje nesudjelovanje na tržištu rada (Bound, 1991.). Kako bi zaobišli ovaj problem, pojedini autori (Dwyer i Mitchell, 1999.;

\footnotetext{
${ }^{1}$ Riječ je o kvantitativnom cilju stope zaposlenosti starijih radnika (dob 55 - 64) koji je 2001. u Stockholmu postavilo Europsko vijeće.
} 
Cai i Kalb, 2006.; Blundell i sur., 2017.) upotrebljavaju objektivne zdravstvene pokazatelje kao instrumente za SRH. Kalwij i Vermeulen (2008.), međutim, ističu da je SRH endogen zato što objektivni zdravstveni pokazatelji nisu uključeni u analizu te predlažu da ih se uključi kao kontrolne varijable, uz pretpostavku da SRH možda nudi dodatne informacije o zdravlju koje objektivni zdravstveni pokazatelji ne odražavaju. Po njima bi u tom slučaju i SRH i objektivni zdravstveni pokazatelji bili povezani s participacijom na tržištu rada. SHARE nudi sveobuhvatnu i multidisciplinarnu bazu podataka koja uključuje širok raspon zdravstvenih pokazatelja, što omogućuje da se istovremeno razmotri više dimenzija zdravlja i da se endogenost SRH-a tretira kao problem izostavljenih varijabli. Ovaj rad ocjenjuje relativnu važnost učinaka različitih zdravstvenih pokazatelja na odluke o ponudi rada u kasnijoj radnoj dobi u Hrvatskoj, a fokus je na učinku SRH-a i na utvrđivanju mijenja li se taj učinak i na koji način kad se u obzir uzmu i objektivniji zdravstveni pokazatelji. U radu se ispituje zadržava li SRH nezavisan učinak na zaposlenost u kasnijoj životnoj dobi ili se taj učinak gubi kad se objektivni zdravstveni pokazatelji uključe u analizu kao kontrolne varijable.

U nastavku rada najprije se donosi pregled relevantne literature o povezanosti zdravlja s ishodima na tržištu rada, zatim se opisuju upotrijebljeni podatci i metode, a nakon toga proizašli rezultati. Zaključak sadrži i praktičnu raspravu namijenjenu nositeljima javnih politika i unaprjeđenju javnih politika.

\section{Pregled literature}

U ovom radu zdravlju se pristupa kao sastavnici ljudskog kapitala i u tom okviru zdravlje se povezuje s položajem na tržištu rada. Na poboljšanje fizičkog i psihičkog zdravlja može se gledati kao na investiciju u ljudski kapital (Becker, 1962.). U svojemu poznatom radu Grossman (1972.) upotrebljava teoriju ljudskog kapitala kako bi objasnio potražnju za „dobrim zdravljem“ i zdravstvenom skrbi kao potrošačkim dobrima. Njegov model pretpostavlja da svaka osoba raspolaže s početnom zalihom zdravstvenog kapitala koja se s dobi smanjuje, no ljudi tu zalihu mogu povećati ulaganjem, primjerice, u zdravstvene usluge, školovanje i usavršavanje na radnom mjestu (Grossman, 2000.; 2008.).

Istraživanja usmjerena na pojedinačne zemlje (npr. Cai i Kalb, 2006.; Leung i Wong, 2002.), kao i međunarodne usporedne analize (npr. Brugiavini, Croda i Mariuzzo, 2005.; Alavinia i Burdorf, 2008.; Kalwij i Vermeulen, 2008.; Bambra i Eikemo, 2008.; Trevisan i Zantomino, 2016.; Reeuwijk i sur., 2017.) pokazuju da su i subjektivni i objektivni zdravstveni pokazatelji važni u donošenju odluka o participaciji na tržištu rada. SRH se smatra subjektivnim zdravstvenim pokazateljem. Vrlo je informativan pokazatelj općeg zdravlja (Idler i Benyamini, 1997.) i dobar je za predviđanje morbiditeta, invalidnosti i mortaliteta među starijima (Jylhä, 2009.). Premda se često upotrebljava u istraživanjima o činiteljima participacije na tržištu rada, upotreba SRH-a može biti problematična iz nekoliko razloga. Primjerice, Bound (1991.) ističe da ljudi koji ne rade mogu upotrijebiti svoja zdravstvena ograničenja ili loše ocijeniti svoje zdravlje kako bi opravdali svoju neparticipaciju. Osim toga, budući da je zdravlje oblik ljudskog kapitala i budući da ljudi mogu ulagati u vlastito zdravlje, održavanje zdravlja trebalo bi biti zajednički određeno ponudom rada i potrošnjom i moglo bi ovisiti o neopaženim karakteristikama, kao što su pojedinačne preferencije (Cai i Kalb, 2006.). Objektivni zdravstveni pokazatelji, s druge strane, nude informacije o, primjerice, biomarkerima, kao što su snaga stiska šake i indeks tjelesne mase (body mass indeks - BMI), dosad 
dijagnosticiranim bolestima ili simptomima bilo fizičkih ili mentalnih oboljenja (npr. Cai i Kalb, 2006:246.; Kalwij i Vermeulen, 2008:627.). Neki autori koriste se objektivnim zdravstvenim pokazateljima kao instrumentima za SRH (Blundell i sur., 2017.), dok Kalwij i Vermeulen (2008.), međutim, ističu da bi se objektivni zdravstveni pokazatelji trebali upotrebljavati u kombinaciji sa SRH-om jer bi različiti zdravstveni pokazatelji mogli odražavati različite dimenzije zdravlja. Sustavan pregled literature o mjerenju zdravlja i kvaliteti pokazatelja o zdravlju dostupan je u Barnay (2016.).

Koristeći se anketnim podatcima o australskim radnicima (u dobi 15 - 49 i 50 - 64), Cai i Kalb (2006.) pokazuju da bolje zdravlje povećava vjerojatnost participacije na tržištu rada. Njihovi zdravstveni pokazatelji obuhvatili su SRH, pet kroničnih bolesti i samoizvedenu mjeru većih ozljeda. Još jedno istraživanje koje se koristi panel podatcima iz Household, Income and Labour Dynamics in Austria (HILDA) ankete potvrđuje ove nalaze, s posebnim naglaskom na obrazovanju kao još jednoj važnoj odrednici participacije na tržištu rada (Laplagne, Glover i Shomos, 2007.). Važnost obrazovanja podupiru i nalazi koji sugeriraju da visokoobrazovani ljudi učinkovitije održavaju svoje zdravlje (Lleras-Muney, 2005.) i da obrazovanje utječe na proizvodnu učinkovitost (Grossman, 2008.). Zdravlje je prepoznato kao odrednica zaposlenosti, ali ne i obrnuto, i u istraživanju koje se koristilo presječnim podatcima o hongkonškom stanovništvu (Leung i Wong, 2002.). Mauer, Klein i Vella (2011.) pokazali su da loše zdravlje i zdravstvena ograničenja povećavaju šanse za izlazak s tržišta rada među starijim muškarcima u SAD-u.

U mnogim studijama upotrijebljeni su presječni ili panel podatci iz SHARE baze kako bi se istražila povezanost zdravlja s ishodima na tržištu rada (npr. Alavinia i Burdorf, 2008.; Kalwij i Vermeulen, 2007.; Trevisan i Zantomino, 2016.; Reeuwijk i sur., 2017.). Jedna od njih (Alavinia i Burdorf, 2008:42.) zaključuje da je „... loš SRH (Europljana u dobi 50 - 64) povezan s neparticipacijom na tržištu rada u vidu preranog umirovljenja, nezaposlenosti i bavljenja obavezama u kućanstvu“. Ista studija spomenute ishode na tržištu rada povezuje s nekoliko kroničnih zdravstvenih stanja, kao što su moždani udar, dijabetes i mišićno-koštana bolest. Međutim, iako su invalidnost i ekonomska neaktivnost u mnogim europskim zemljama blisko povezani, pri čemu naknade za invalidnost premašuju naknade za nezaposlenost (Haveman, 2000.), jedno istraživanje utemeljeno na SHARE podatcima ukazuje na poprilično visoke udjele umirovljenika bez zdravstvenih ograničenja (Brugiavini, Croda i Mariuzzo, 2005.).

Loše zdravlje svakako je snažan poticaj za izlazak s tržišta rada, no zemlje se međusobno razlikuju prema apsolutnom riziku od preranog umirovljenja ili ekonomske neaktivnosti. U istraživanju kojim je obuhvaćeno šesnaest europskih zemalja Trevisan i Zantomino (2016.) pronalaze dvostruko veće šanse za izlazak s tržišta rada među starijim radnicima koji su doživjeli akutne zdravstvene šokove. Reeuwijk i sur. (2017.) ističu da loš SRH među starijim radnicima u Europi povećava rizik za izlazak s tržišta rada, ali da taj učinak varira među zemljama. Kalwij i Vermeulen (2008.) također upotrebljavaju brojne i raznovrsne pokazatelje o zdravlju iz SHARE baze, istražujući povezanost zdravlja s participacijom starijeg stanovništva na tržištu rada u jedanaest europskih zemalja i endogenosti SRH-a pristupaju kao problemu izostavljenih varijabli. Teška i blaga kronična zdravstvena stanja, funkcionalna ograničenja, snaga stiska šake, BMI i pokazatelj mentalnog zdravlja u njihovu analizu ulaze kao objektivni zdravstveni pokazatelji. Nalazi sugeriraju da je u nekim zemljama SRH prilično pouzdan pokazatelj zdravlja, dok u drugima 
subjektivni (SRH) i objektivni zdravstveni pokazatelji imaju zasebne učinke na participaciju na tržištu rada u starijoj dobi.

Ovaj rad istražuje kako je SRH povezan s participacijom na tržištu rada u Hrvatskoj - zadržava li svoj nezavisan učinak i nakon što se u analizu uključe objektivni zdravstveni pokazatelji ili objektivni zdravstveni pokazatelji objašnjavaju povezanost SRH-a i zaposlenosti u starijoj radnoj dobi?

\section{Metode}

Ovaj rad temelji se na podatcima iz šeste runde SHARE istraživanja (Börsch-Supan, 2019.). SHARE je multidisciplinarno i međunarodno panel istraživanje kojim se prikupljaju detaljni podatci o zdravlju, socioekonomskom statusu, obitelji i društvenim mrežama starijih Europljana. SHARE uključuje ispitanike $\mathrm{u}$ dobi od $50+\mathrm{i}$ njihove partner(ic)e bilo koje dobi. Zasniva se na probabilističkim uzorcima i reprezentativan je za starije stanovnike koji žive samostalno odnosno u obitelji, a ne u nekoj instituciji. Podatci se prikupljaju računalno potpomognutim osobnim intervjuima. Hrvatska se pridružila SHARE-u u šestoj rundi, a od lipnja do studenog 2015. trajao je terenski rad (više detalja potražiti u Malter i Börsch-Supan, 2017.). Analiza u ovom radu ograničena je na ispitanike iz Hrvatske koji su intervjuirani u šestoj rundi i koji su u vrijeme intervjua bili u dobi 50 - 64. Tako zadan uzorak sadrži 1287 opažanja (što čini oko 51,6\% ukupnog uzorka iz šeste runde za Hrvatsku).

Za obradu podataka i statističku analizu upotrijebljena je STATA 15 (StataCorp, 2017.). Svi STATA kodovi uz pripadajuće rezultate dostupni su od autorā na zahtjev.

\subsection{VARIJABLE}

Zavisna varijabla izvedena je iz pitanja o trenutnome radnom statusu. Izvorna skala s odgovorima sadrži šest kategorija: umirovljen/a, zaposlen/a ili samozaposlen/a, nezaposlen/a, trajno bolestan/osoba s invaliditetom, osoba koja se bavi obavezama u kućanstvu i ostalo. Te su vrijednosti svedene na dvije kategorije, s kategorijom zaposlenosti odvojenom od svih ostalih kategorija. Prema nekim autorima (npr. Kalwij i Vermeulen, 2008.), osobe koje u dobi 50 - 64 nisu zaposlene u svojevrsnoj su predmirovini. Zavisna je varijabla, dakle, binarna i pokazuje radi li ispitanik ili ne radi.

Kako bi se u obzir uzela višedimenzionalna priroda zdravstvenog stanja (Kalwij i Vermeulen, 2008.), u analizu je uvršteno nekoliko objašnjavajućih varijabli koje se odnose na zdravlje. Subjektivno (samoprocijenjeno) zdravlje izmjereno je na skali od 1 (odličan SRH) do 5 (loš SRH). Ta je varijabla centrirana oko 3 (dobar SRH) zbog lakše interpretacije. ${ }^{2}$ Analiza uz SRH sadrži i niz objektivnih zdravstvenih pokazatelja. Razmatraju se sljedeći:

(a) Broj kroničnih bolesti. SHARE nudi popis s više od dvadeset kroničnih bolesti svakom ispitaniku, te oni odabiru koje su im od ponuđenih kroničnih bolesti ikad dijagnosticirane. Odgovori se potom sabiru u jednu varijablu, dostupnu u SHARE bazi.

\footnotetext{
2 Različita istraživanja koriste se različitim specifikacijama SRH-a. Mnogi autori odabiru dihotomnu skalu (npr. Desesquelles, Egidi i Salvatore, 2009.; Giatti, Barreto i César, 2010.; Zajacova i Dowd, 2011.). Naši se zaključci bitno ne mijenjaju ako se upotrijebi binarna SRH varijabla (cijela je analiza provedena is dvije inačice binarnog SRH-a, koje redom pokazuju vrlo dobar ili odličan SRH naspram dobrog ili lošijeg SRH-a, odnosno loš ili zadovoljavajući SRH naspram dobrog ili boljeg SRH-a).
} 
(b) Broj poteškoća s (instrumentalnim) aktivnostima svakodnevnog života ((instrumental) activities of daily living), (I)ADL-ovi. SHARE pita susreće li se ispitanik zbog „fizičkih mentalnih, emocionalnih ili problema s pamćenjem“s „ikakvim poteškoćama“ (da ili ne) pri obavljanju ADL-ova - aktivnosti svakodnevnog života (kao što su odijevanje, hodanje po sobi ili uzimanje hrane) ili IADL-ova - instrumentalnih aktivnosti svakodnevnog života (kao što su pripremanje toplog jela, kupovina namirnica ili uzimanje lijekova). Broj ADL-ova i broj IADL-ova zbrojeni su u jednu varijablu koja se kreće u rasponu od 0 do 15 (broj aktivnosti s naznačenim poteškoćama). Kombinirana skala koja uključuje i ADL-ove i IADLove preporučuje se u literaturi (npr. Spector i Fleishman, 1998.; LaPlante, 2010.).

(c) Broj simptoma depresije. Ova varijabla pokazuje odgovore koje su ispitanici dali na EURODepression skali koja je razvijena za mjerenje depresije u kasnijoj životnoj dobi u Europi (Castro-Costa i sur., 2007.) i kreće se od 0 do 12 samoprocijenjenih simptoma (kao što je osjećaj krivnje, gubitak apetita ili tuga).

(d) Snaga stiska šake. Riječ je o važnoj stavci za mjerenje kako ljudi stare: dobar je prediktor invalidnosti, morbiditeta i mortaliteta (npr. Andersen-Ranberg i sur., 2009.). SHARE uključuje varijablu koja pokazuje maksimalnu snagu stiska šake iz dvaju mjerenja dinamometrom na svakoj ruci. Kako bi se uvažile muško-ženske razlike, u ovu analizu ulazi varijabla koja je stvorena tako da pokazuje kvintile snage stiska šake specifične prema spolu. Kvintili se upotrebljavaju umjesto (po spolu centrirane) kontinuirane varijable kako bi se u analizi mogli zadržati i ispitanici s nepoznatim vrijednostima snage stiska šake (više od 7\% uzorka) pod zasebnom kategorijom „nepoznato“.

(e) Indeks tjelesne mase (BMI). Varijabla je centrirana oko 25, praga za prekomjernu tjelesnu masu (WHO, 2000.; Nuttall, 2015.).

U analizi su također razmotrene dvije varijable koje se tiču rizičnoga zdravstvenog ponašanja: pijenje i pušenje. Varijabla o pijenju pokazuje broj jedinica alkoholnih pića tijekom posljednjih sedam dana, a varijabla o pušenju pokazuje prosječnu broj cigareta koje ispitanik popuši dnevno. Obje varijable kretale su se od 0 do 60 u našem uzorku. Univarijatna analiza ne upućuje na značajan učinak pušenja, no upućuje na pozitivan učinak pijenja na zaposlenost. Takva „obrnuta uzročnost“ nije rijetkost u epidemiološkim istraživanjima (Rothman i Greenland, 2005.; Sieminska i sur., 2008.; Balsa i sur., 2008.) jer bi se ljudi s lošijim zdravljem mogli u većoj mjeri suzdržavati od pijenja i pušenja. Iz tog razloga ove su varijable izostavljene iz naših modela.

Kontrolne su varijable u analizi dob (i kvadrirana dob), spol, interakcija dobi sa spolom, životni aranžmani (suživot s partnerom, samački život ili život s ostalima bez partnera u kućanstvu), broj djece $^{3}$ i obrazovanje (nisko, srednje ili visoko, prema ISCED 2011 klasifikaciji obrazovnih kategorija prikupljenih SHARE-om).

\footnotetext{
${ }^{3}$ Svako SHARE kućanstvo odabire samo jednog člana da odgovara na pitanja o obitelji, te samo on odgovara na pitanja o djeci. Kako bi se omogućila analiza na pojedinačnoj razini, odgovori o djeci koje su dali ispitanici za obitelj kopirani su i za njihove partner(ic)e unutar istog kućanstva.
} 


\subsection{ModeLI}

Budući da je zavisna varijabla binarna, za procjenu povezanosti zdravlja sa zaposlenjem u starijoj radnoj dobi u Hrvatskoj, koristimo se modelima logističke regresije. Prije procjene modelā iz analize je isključeno 39 ispitanika s nedostajućim podatcima o radnom statusu ili bilo kojoj od eksplanatornih varijabli (iznimka je snaga stiska šake, vidjeti prethodno poglavlje). Modeli su građeni postepeno da bi se bolje razumjelo kako se učinak SRH-a mijenja s uključivanjem drugih varijabli o zdravlju. Najprije je procijenjen osnovni model (Model 1.), koji uključuje samo SRH varijablu, a potom je dodan i niz objektivnih zdravstvenih pokazatelja (Model 2.). Regresijski modeli nisu ponderirani, no vodi se računa o klasteriranju na razini kućanstva. Važno je prepoznati da opažanja u uzorku nisu nezavisna jer istraživanja pokazuju da su partneri skloni usklađivanju odluka o zaposlenju/umirovljenju (Gustman i Steinmeier, 2001.; Ozawa i Lum, 2005.; Bađun i Smolić, 2018.).

U interpretaciji rezultata upotrebljavaju se dva pokazatelja. Najprije se iznose omjeri šansi, odnosno potencirani regresijski koeficijenti. Pozitivan koeficijent odgovara omjeru šansi većem od 1, dok negativan koeficijent odgovara omjeru šansi manjem od 1 . U ovom slučaju omjeri šansi pokazuju kako se šanse zaposlenja, u usporedbi sa šansama nezaposlenja, mijenjaju s jediničnim povećanjem eksplanatorne varijable (uz pretpostavku da su sve druge eksplanatorne varijable konstantne). Uz omjere šansi također se iznose procijenjene razlike u vjerojatnostima zaposlenja (tj. prosječni granični učinci) za svaku od zdravstvenih eksplanatornih varijabli iz dvaju modela.

\section{EMPIRIJSKI NALAZI}

U nastavku je prvo izložena deskriptivna statistika. Tablica 1. sadrži prosjeke odnosno postotne udjele, kako je prikladno, prema radnom statusu, za sve varijable uključene u analizu. Ukupno gledajući, uzorak sadrži 35\% ispitanika koji su zaposleni i 65\% ispitanika koji nisu zaposleni. Ispitanici u prosjeku imaju 57,87 godina i u uzorku je više žena nego muškaraca. Ispitanici pretežno žive s partner(ic)ama u dvočlanim kućanstvima i u prosjeku imaju 1,9 djece. Primjetne su velike razlike u postignutom obrazovanju s obzirom na radni status. Što se tiče zdravlja, prosječna vrijednost SRH-a u uzorku iznosi 3,05 i kod zaposlenih ispitanika pronalazimo niže vrijednosti (odnosno bolje zdravlje) nego kod ispitanika koji nisu zaposleni. Kod zaposlenih ispitanika, u usporedbi s ispitanicima koji nisu zaposleni, pronalazimo manje kroničnih bolesti, (I)ADL-ova i simptoma depresije, veću prosječnu snagu stiska šake i niži BMI.

Pogledajmo zatim procjene iz Modela 1. koji uključuje sve kontrolne varijable i SRH kao jedinu zdravstvenu varijablu. Model dopušta nelinearne dobne učinke (sadrži kvadriranu dob) i uključuje interakciju dobi i spola kako bi se uvažile razlike među spolovima u ponudi rada u starijoj radnoj dobi. Omjer šansi uz SRH $(\mathrm{p}<0,001)$ sugerira da se šanse za zaposlenost smanjuju za 31,6\% s jediničnim povećanjem SRH-a. To znači da se izgledi za zaposlenost smanjuju s pogoršanjem zdravstvenog stanja (odnosno s povećanjem vrijednosti SRH-a). Ovaj rezultat, osim koristeći se omjerom šansi, možemo interpretirati i u obliku prosječnoga graničnog učinka. U prvom stupcu Tablice 3. procijenjeno je kako se vjerojatnost za zaposlenost mijenja s jediničnom promjenom SRH-a: jedinično pogoršanje SRH-a snižava vjerojatnost za zaposlenost za 6,5 postotnih bodova.

Model 2. uz SRH sadrži i objektivnije zdravstvene pokazatelje. U ovoj analizi nisu pronađeni dokazi o endogenosti SRH-a zbog izostavljanja objektivnih zdravstvenih pokazatelja: učinak SRH-a gubi se kad 
se kontrolira za dodatne, objektivnije pokazatelje o zdravlju. Isprva snažan i značajan učinak SRH-a izostaje u Modelu 2. Kako prikazuje Tablica 3., pad vjerojatnosti za zaposlenost izazvan jediničnim pogoršanjem zdravlja spušta se s 6,5 postotnih bodova (uz $\mathrm{p}<0,001$ ) u Modelu 1 . na tek 1,6 postotnih bodova (uz p = 0,195) u Modelu 2.

\section{TABLICA 1.}

Deskriptivna statistika

\begin{tabular}{|c|c|c|c|c|c|}
\hline \multirow{2}{*}{ Varijabla } & \multicolumn{2}{|c|}{ Poznati $\mathbf{N}^{a}$} & \multicolumn{3}{|c|}{$\begin{array}{c}\text { Prosjek (standardna devijacija) ili postotni } \\
\text { udjel }\end{array}$} \\
\hline & Zaposleni & $\begin{array}{c}\text { Nisu } \\
\text { zaposleni }\end{array}$ & Zaposleni & $\begin{array}{c}\text { Nisu } \\
\text { zaposleni }\end{array}$ & Svi ispitanici \\
\hline Dob & 451 & 831 & $\begin{array}{l}56,28 \\
(3,50)\end{array}$ & $\begin{array}{l}58,74 \\
(3,81)\end{array}$ & $\begin{array}{l}57,87 \\
(3,88)\end{array}$ \\
\hline Spol & 451 & 831 & & & \\
\hline Žene (\%) & & & 48,56 & 61,37 & 56,86 \\
\hline Muškarci (\%) & & & 51,44 & 38,63 & 43,14 \\
\hline Životni aranžmani & 451 & 831 & & & \\
\hline Živi s partner(ic)om (\%) & & & 86,92 & 81,47 & 83,39 \\
\hline Živi sam/a (\%) & & & 8,87 & 10,35 & 9,83 \\
\hline Živi s drugima (\%) & & & 4,21 & 8,18 & 6,79 \\
\hline Djeca & 450 & 831 & $\begin{array}{c}1,77 \\
(0,88)\end{array}$ & $\begin{array}{c}1,97 \\
(1,02)\end{array}$ & $\begin{array}{c}1,90 \\
(0,98)\end{array}$ \\
\hline Obrazovanje & 451 & 830 & & & \\
\hline Nisko (\%) & & & 9,76 & 33,37 & 25,06 \\
\hline Srednje (\%) & & & 62,97 & 57,47 & 59,41 \\
\hline Visoko (\%) & & & 27,27 & 9,16 & 15,53 \\
\hline SRH & 451 & 831 & $\begin{array}{c}2,60 \\
(1,06)\end{array}$ & $\begin{array}{c}3,30 \\
(1,18)\end{array}$ & $\begin{array}{c}3,05 \\
(1,18)\end{array}$ \\
\hline Kronične bolesti & 451 & 831 & $\begin{array}{c}0,86 \\
(1,03)\end{array}$ & $\begin{array}{c}1,71 \\
(1,53)\end{array}$ & $\begin{array}{c}1,41 \\
(1,44)\end{array}$ \\
\hline (I)ADL-ovi & 451 & 831 & $\begin{array}{c}0,05 \\
(0,29)\end{array}$ & $\begin{array}{c}0,42 \\
(1,72)\end{array}$ & $\begin{array}{c}0,29 \\
(1,40)\end{array}$ \\
\hline Simptomi depresije & 446 & 821 & $\begin{array}{c}1,69 \\
(1,90)\end{array}$ & $\begin{array}{c}2,64 \\
(2,38)\end{array}$ & $\begin{array}{c}2,30 \\
(2,27)\end{array}$ \\
\hline Snaga stiska šake & 421 & 773 & $\begin{array}{c}40,04 \\
(12,29)\end{array}$ & $\begin{array}{c}35,90 \\
(11,77)\end{array}$ & $\begin{array}{c}37,36 \\
(12,11)\end{array}$ \\
\hline BMI & 444 & 819 & $\begin{array}{l}26,64 \\
(4,04)\end{array}$ & $\begin{array}{l}27,65 \\
(4,71)\end{array}$ & $\begin{array}{l}27,29 \\
(4,51)\end{array}$ \\
\hline
\end{tabular}

a Vrijednosti nisu ponderirane.

Izvor: Izračuni autorā temeljem podataka iz šeste runde SHARE-a.

Procijenjeni omjeri šansi iz specificiranih modela logističke regresije prikazani su u Tablici 2. Prvi stupac sadrži univarijatne omjere šansi (rezultate iz modelā samo s jednim prediktorom, koji su procijenjeni jedan po jedan). Ključan je nalaz da su sve odabrane varijable povezane sa šansama zaposlenja; sve zdravstvene varijable pokazuju snažne i signifikantne učinke (uz p-vrijednosti ispod 0,001$)$ osim snage stiska šake $(p<0,10)$. 
TABLICA 2.

Procijenjeni omjeri šansi iz logističke regresije

\begin{tabular}{|c|c|c|c|}
\hline $\begin{array}{c}\text { Varijable } \\
\text { (ref. označuje referentne } \\
\text { vrijednosti za kategorijske } \\
\text { varijable) }\end{array}$ & $\underset{\text { šansi }}{\text { Univarijatni omjer }}$ & Model 1 & Model 2 \\
\hline $\operatorname{Dob}^{a}$ & $0,837^{* * *}$ & 1,215 & 1,205 \\
\hline Kvadrirana dob & & $0,977^{* * *}$ & $0,977^{* * *}$ \\
\hline \multicolumn{4}{|l|}{ Spol } \\
\hline Muškarci & ref. & ref. & ref. \\
\hline Žene & $0,585^{* * *}$ & 1,973 & 1,842 \\
\hline \multicolumn{4}{|l|}{ Interakcija dobi sa spolom } \\
\hline Dob x žene & & $0,734^{*}$ & $0,740^{*}$ \\
\hline Kvadrirana dob x žene & & 1,015 & 1,016 \\
\hline \multicolumn{4}{|l|}{ Životni aranžmani } \\
\hline Živi s partner(ic)om & ref. & ref. & ref. \\
\hline Živi sam/a & 0,817 & 0,735 & 0,707 \\
\hline Živi s drugim/a & $0,501^{* *}$ & $0,467^{* *}$ & $0,536^{* *}$ \\
\hline Djeca & $0,811^{* * *}$ & $0,810^{* * *}$ & $0,825^{* *}$ \\
\hline \multicolumn{4}{|l|}{ Obrazovanje } \\
\hline Nisko & $0,267^{* * *}$ & $0,401^{* * *}$ & $0,412^{* * *}$ \\
\hline Srednje & ref. & ref. & ref. \\
\hline Visoko & $2,641^{* * *}$ & $3,259 * * *$ & $3,527^{* * *}$ \\
\hline $\mathrm{SRH}^{b}$ & $0,590^{* * *}$ & $0,684^{* * *}$ & 0,905 \\
\hline Kronične bolesti & $0,582^{* * *}$ & & $0,719^{* * *}$ \\
\hline (I)ADL-ovi & $0,552^{* * *}$ & & $0,814^{* *}$ \\
\hline Simptomi depresije & $0,812^{* * *}$ & & $0,934 *$ \\
\hline \multicolumn{4}{|l|}{ Snaga stiska šakec } \\
\hline Prvi kvintil & $0,702^{*}$ & & 1,106 \\
\hline Drugi kvintil & 0,852 & & 0,982 \\
\hline Treći kvintil & ref. & & ref. \\
\hline Četvrti kvintil & 1,236 & & 1,036 \\
\hline Peti kvintil & $1,467^{*}$ & & 1,175 \\
\hline $\mathrm{BMI}^{d}$ & $0,946^{* * *}$ & & $0,968^{*}$ \\
\hline Konstanta & & 1,291 & 2,262 \\
\hline $\mathrm{N}$ & 1.248 & 1248 & 1248 \\
\hline Klasterā u uzorku & 868 & 868 & 868 \\
\hline Waldov Hi kvadrat & & $225.03^{* * *}$ & $252,34^{* * *}$ \\
\hline
\end{tabular}

${ }^{*} p<0,10 ;{ }^{* *} p<0,05 ;{ }^{* *} p<0,01$. a Vrijednosti su centrirane oko dobi od 50 godina. ${ }^{b}$ Vrijednosti su centrirane oko 3 (dobar SRH) c Uključena su i opažanja s nedostajućim podatcima o snazi stiska šake, nepoznate vrijednosti tretirane su kao zasebna kategorija; međutim, procijenjeni omjeri šansi nisu prikazani (nisu statistički signifikantni). ${ }^{d}$ Vrijednosti su centrirane oko 25 (prag BMI-a za prekomjernu tjelesnu masu).

Izvor: Izračuni autorā temeljem podataka iz šeste runde SHARE-a.

U Modelu 2. samo objektivni zdravstveni pokazatelji značajno utječu na participaciju na tržištu rada u starijoj radnoj dobi u Hrvatskoj. Primjerice, svaka dodatna kronična bolest smanjuje šanse za zaposlenost za 28,1\% (vidjeti Tablicu 2.). To se može preračunati u smanjenje vjerojatnosti za zaposlenost u iznosu od 5,4 postotna boda sa svakom dodatnom kroničnom bolesti (vidjeti Tablicu 3.). 
TABLICA 3.

Prosječni granični učinci zdravstvenih varijabli

\begin{tabular}{|c|c|c|}
\hline Varijable & Model 1 & Model 2 \\
\hline SRH & $-0,065^{* * *}$ & $-0,016$ \\
\hline Kronične bolesti & & $-0,054^{* * *}$ \\
\hline (I)ADL-ovi & & $-0,034^{* *}$ \\
\hline Simptomi depresije & & $-0,011^{*}$ \\
\hline \multicolumn{3}{|l|}{ Snaga stiska šake po kvintilimaa } \\
\hline Prvi & & 0,017 \\
\hline Drugi & & $-0,003$ \\
\hline Treći & & ref. \\
\hline Četvrti & & 0,006 \\
\hline Peti & & 0,027 \\
\hline BMI & & $-0,005^{*}$ \\
\hline
\end{tabular}

${ }^{*} p<0,10,{ }^{* *} p<0,05 ;{ }^{* *} p<0,01$. a Prosječni granični učinci za kategorije kategorijske varijable diskretne su promjene u odnosu na referentnu kategoriju (ref.).

Izvor: Izračuni autorā temeljem podataka iz šeste runde SHARE-a.

Ovi nalazi sugeriraju da u Hrvatskoj SRH snažno korelira s objektivnim zdravstvenim pokazateljima. To potvrđuje i dodatna analiza (rezultati su dostupni od autorā na zahtjev); SRH je u snažnoj vezi sa svim upotrijebljenim objektivnim zdravstvenim pokazateljima (uz p-vrijednosti ispod 0,001 za kronične bolesti, (I)ADL-ove i simptome depresije i uz p < 0,10 za snagu stiska šake i BMI).

Na Grafikonu 1. uspoređuju se procijenjene vjerojatnosti zaposlenja s obzirom na vrijednosti SRH-a iz dviju modelskih specifikacija. Ponovimo da u Modelu 2., međutim, objektivni zdravstveni pokazatelji preuzimaju ulogu koja je isprva pripadala SRH-u, čiji se statistički signifikantan učinak pronalazi samo u Modelu 1.

\section{GRAFIKON 1.}

Procijenjene vjerojatnosti za zaposlenost prema SRH-u

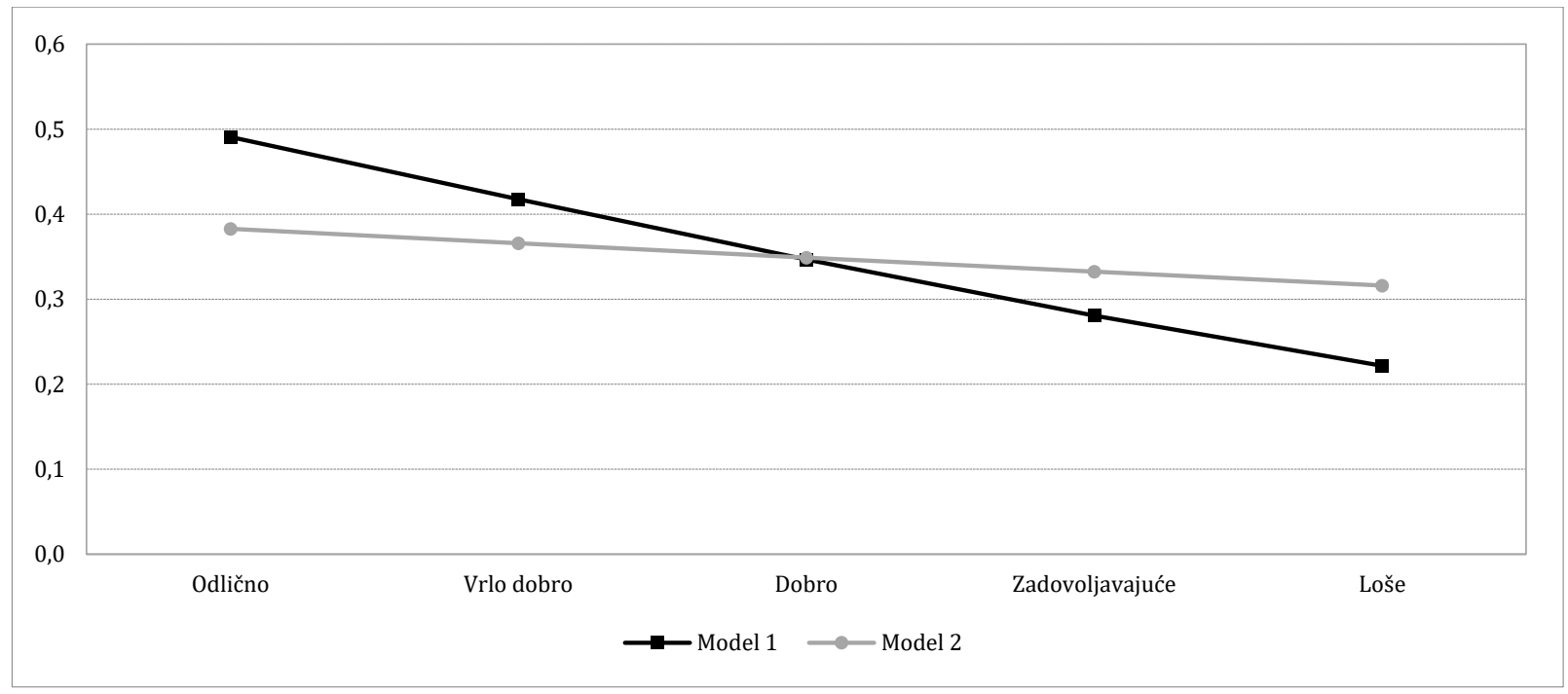

Izvor: Autori. 
Četiri grafikona na Grafikonu 2. pokazuju kako se vjerojatnosti za zaposlenost prema dobivenim rezultatima mijenjaju s objektivnim zdravstvenim pokazateljima koji su imali (barem granično) signifikantne učinke u Modelu 2. Kako bi se olakšala usporedba, okomite osi na grafikonima postavljene su tako da su ekvidistantne.

\section{GRAFIKON 2.}

Procijenjene vjerojatnosti za zaposlenost prema objektivnim zdravstvenim pokazateljima
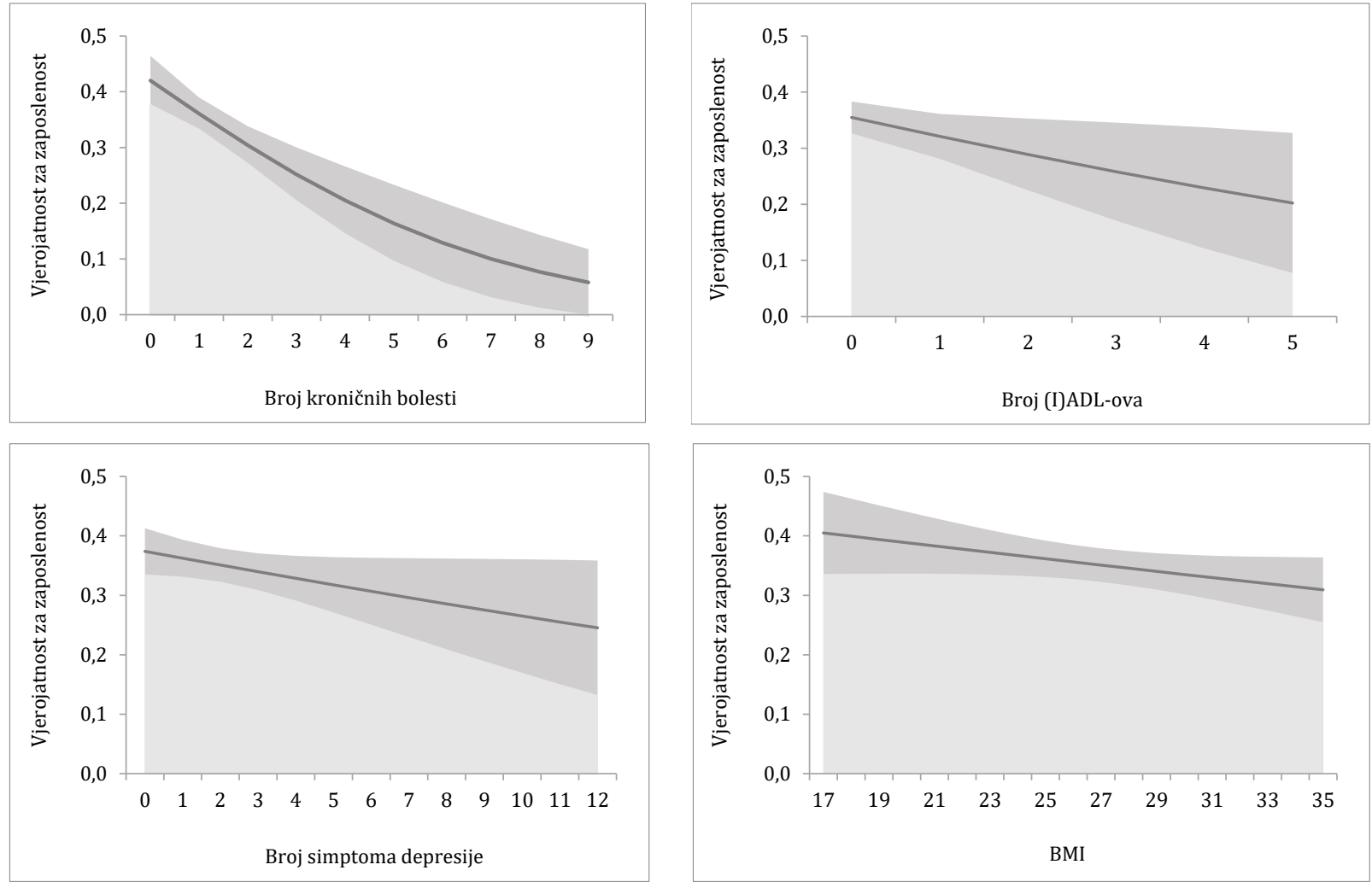

Izvor: Autori.

\section{Zaključak}

Cilj ovog rada bio je istražiti povezanost općeg zdravlja sa zaposlenošću tijekom kasnijega radnog vijeka u Hrvatskoj. Koristeći se recentnim podatcima iz SHARE-a, ovaj rad doprinosi dosadašnjim spoznajama o povezanosti zdravlja s ishodima na tržištu rada među starijim stanovništvom u Hrvatskoj. Podatci iz SHARE-a omogućili su da se uz SRH razmotri i skup objektivnih zdravstvenih varijabli i da se ispita imaju li subjektivno i objektivno zdravlje nezavisne učinke na zaposlenost u starijoj radnoj dobi u Hrvatskoj ili mogu funkcionirati kao supstituti. Prvo je procijenjen model u kojem je SRH uključen kao jedina zdravstvena varijabla, a potom su u sljedećoj specifikaciji dodani i objektivni zdravstveni pokazatelji. Pokazalo se da se učinak SRH-a gubi kad se u analizu uključe i druge (objektivnije) zdravstvene varijable. Budući da su u drugoj specifikaciji objektivni zdravstveni pokazatelji preuzeli ulogu koju je u prvoj specifikaciji imao SRH, može se zaključiti da se u istraživanjima o participaciji na tržištu rada u starijoj radnoj dobi u Hrvatskoj kao mjera općeg zdravlja može upotrebljavati SRH samostalno ili se može upotrebljavati kombinacija objektivnih zdravstvenih pokazatelja (Kalwij i Vermeulen, 2008.). Rezultati pokazuju da loše zdravlje, mjereno 
bilo subjektivnim (SRH-om) bilo objektivnim pokazateljima, smanjuje vjerojatnost za zaposlenost u kasnijoj radnoj dobi u Hrvatskoj.

Na tržištu rada u Hrvatskoj javlja se ozbiljan nedostatak radne snage u mnogim sektorima, a tome itekako doprinosi starenje stanovništva. Iako su stope zaposlenosti za stanovništvo u dobi do 50 godina blizu europskog prosjeka, stope zaposlenosti među starijim stanovništvom znatno su niže. Osim ako Hrvatska ne dopusti neograničenu imigraciju, jedina opcija koja preostaje u srednjem roku jest povećanje broja starijih ljudi koji rade. Međutim, pred nositeljima javnih politika kao prepreka toj opciji moglo bi se javiti zdravstveno stanje starijeg stanovništva i rezultati iz ovog rada idu toj pretpostavci u prilog.

Rezultati provedene analize izraženi su i kao prosječni granični učinci kako bi se stvorila što jasnija i jednostavnija znanstvena podloga za donošenje javnih politika, zato što je poticanje aktivnog zaposlenja u starijoj dobi presudno za zemlje suočene s demografskim padom. Kako ističu Brugiavini, Croda i Mariuzzo (2005.), velikodušnost mirovinskog sustava može istisnuti još uvijek dovoljno zdrave ljude s tržišta rada. Međutim, povezanost zdravlja s participacijom na tržištu rada u starijoj radnoj dobi nikako se ne smije zanemariti pri planiranju reformi mirovinskog i zdravstvenog sustava i radnog zakonodavstva. Djelokrug javnopolitičkih intervencija u velikoj bi mjeri mogao ovisiti o razumijevanju učinaka koje zdravlje ima na ponudu rada u starijoj dobi. Pod okolnostima kad su mirovinski i zdravstveni sustavi pod velikim pritiskom, nositelji javnih politika moraju pronaći način da stanovništvo bude što duže ekonomski produktivno. Pogoršanje zdravlja dovodi do ranijeg izlaska s tržišta rada. Stoga je potrebno prepoznati adekvatne mehanizme za provedbu zdravstvenih intervencija kako bi se poboljšao radni kapacitet današnjih i budućih kohorti radnikā. Te intervencije trebale bi biti usmjerene na učinkovitije sprječavanje i liječenje dugotrajnih bolesti.

Ograničenje ovog istraživanja jest njegovo oslanjanje na presječne podatke, no longitudinalni podatci - potrebni kako bi se utvrdilo izazivaju li promjene u zdravlju promjene u radnom statusu - za Hrvatsku će biti dostupni tek u narednim godinama. Podatci iz nadolazećih SHARE rundi omogućit će da se buduća istraživanja usmjere na uzročnu povezanost zdravlja s ishodima na tržištu rada među starijim stanovništvom u Hrvatskoj. 


\section{REFERENCE}

1. Alavinia, S. M. i Burdorf, A., 2008. Unemployment and retirement and ill-health: a crosssectional analysis across European countries. International Archives of Occupational and Environmental Health, 82(1), str. 39-45. https://doi.org/10.1007/s00420-008-0304-6

2. Andersen-Ranberg, K. [i sur.], 2009. Cross-national differences in grip strength among 50+ year-old Europeans: results from the SHARE study. European Journal of Ageing, 6(3), str. $227-$ 236. https://doi.org/10.1007/s10433-009-0128-6

3. Bađun, M. i Smolić, Š., 2018. Predictors of Early Retirement Intentions in Croatia. Društvena istraživanja, 27(4), str. 671-690. https://doi.org/10.5559/di.27.4.05

4. Baloković, S., 2011. Prijevremeno umirovljenje u Republici Hrvatskoj. Revija za socijalnu politiku, 18(1), str. 61-76. https://doi.org/10.3935/rsp.v1i1.976

5. Balsa, A. [i sur.], 2008. Alcohol Consumption and Health Among Elders. The Gerontologist, 48(5), str. 622-636. https://doi.org/10.1093/geront/48.5.622

6. Bambra, C. i Eikemo, T. A., 2008. Welfare state regimes, unemployment and health: a comparative study of the relationship between unemployment and self-reported health in 23 European countries. Journal of Epidemiology \& Community Health, 63(2), str. 92-98. https://doi.org/10.1136/jech.2008.077354

7. Barnay, T., 2016. Health, Work and Working Conditions: A Review of the European Economic Literature. European Journal of Health Economics, 17 (6), str. 693-709. https://doi.org/10.1007/s10198-015-0715-8

8. Becker, G. S., 1962. Investment in Human Capital: A Theoretical Analysis. Journal of Political Economy, 70(5, Part 2), str. 9-49.

9. Bejaković, P., 2016. Demografsko starenje i mjere za zadržavanje starijih osoba u svijetu rada, U: A. Akrap, I. Čipin i M. Strmota, ur. Znanstveni skup „Demografija u Hrvatskoj“, Zbornik radova. Zagreb: Ekonomski fakultet - Zagreb, str. 367-390.

10. Blundell, R. [i sur.], 2017. The Impact of Health on Labor Supply Near Retirement. Working paper, 2017-364.

11. Börsch-Supan, A. [i sur.], 2013. Data Resource Profile: The Survey of Health, Ageing and Retirement in Europe (SHARE). International Journal of Epidemiology, 42(4), str. 992-1001. https://doi.org/10.1093/ije/dyt088

12. Börsch-Supan, A., 2019. Survey of Health, Ageing and Retirement in Europe (SHARE) Wave 6. Release version: 7.0.0. Munich: SHARE-ERIC. Data set. https://doi.org/10.1007/978-981-287080-3_243-1

13. Bound, J., 1991. Self-Reported Versus Objective Measures of Health in Retirement Models. Journal of Human Resources, 26(1), str. 106. https://doi.org/10.2307/145718

14. Brugiavini, A., Croda, E. i Mariuzzo, F., 2005. Labour Force Participation of the Elderly: Unused Capacity? U: A. Börsch-Supan [i sur.], ur. Health, ageing and retirement in Europe - First results from the Survey of Health, Ageing and Retirement in Europe. Mannheim: Mannheim Research Institute for the Economics of Aging (MEA). https://doi.org/10.1007/978-981-287-0803_243-1

15. Bubaš, M., Miloš, M. i Delić-Brkljačić, D., 2008. Occupational Diseases, Working Ability and Employment Status in the Working Population of Croatia. Collegium Antropologicum, 32(3), str. 677-680.

16. Cai, L. i Kalb, G., 2006. Health status and labour force participation: evidence from Australia. Health Economics, 15(3), str. 241-261. https://doi.org/10.1002/hec.1053

17. Castro-Costa, E. [i sur.], 2007. Prevalence of depressive symptoms and syndromes in later life in ten European countries: The SHARE study. British Journal of Psychiatry, 191(5), str. 393-401. https://doi.org/10.1192/bjp.bp.107.036772

18. Cicchetti, D. V., Shoinralter, D. i Tyrer, P. J., 1985. The Effect of Number of Rating Scale Categories on Levels of Interrater Reliability: A Monte Carlo Investigation. Applied Psychological Measurement, 9(1), str. 31-36. https://doi.org/10.1177/014662168500900103

19. Deaton, A., 2002. Policy Implications Of The Gradient Of Health And Wealth. Health Affairs, 21(2), str. 13-30. https://doi.org/10.1377/hlthaff.21.2.13 
20. Desesquelles, A.F., Egidi, V. i Salvatore, M. A., 2009. Why do Italian people rate their health worse than French people do? An exploration of cross-country differentials of self-rated health. Social Science \& Medicine, 68(6), str. 1124-1128. https://doi.org/10.1016/j.socscimed.2008.12.037

21. Dwyer, D. S. i Mitchell, O. S., 1999. Health problems as determinants of retirement: Are selfrated measures endogenous? Journal of Health Economics, 18(2), str. 173-193. https://doi.org/10.1016/s0167-6296(98)00034-4

22. Ecimović Nemarnik, R. i Macan, J., 2018. Employment status of workers with a diagnosed occupational disease in Croatia: a 10-year trend (2005-2014). Archives of Industrial Hygiene and Toxicology, 69(3), str. 220-225. https://doi.org/10.2478/aiht-2018-69-3132

23. European Commission, 2011. Employment in Europe. Luxembourg: Publications Office of the European Union.

24. European Commission, 2019. Labour market information - Croatia. EURES - The European Job Mobility Portal.

25. Eurostat, 2019a. Population projections.

26. Eurostat, 2019b. Employment rate of older workers, age group 55-64.

27. Galić, Z., Parmač Kovačić, M. i Vehovec, M., 2019. Quality of Working Life among 50+ Employees across the EU: A Double Jeopardy for Croatian Older Workers. Društvena istraživanja, 28(1), str. 69-87. https://doi.org/10.5559/di.28.1.04

28. Giatti, L., Barreto, S. M. i César, C. C., 2010. Unemployment and self-rated health: Neighborhood influence. Social Science \& Medicine, 71(4), str. 815-823. https://doi.org/10.1016/j.socscimed.2010.05.021

29. Goić, S., 2017. Employees older than 50 on Croatian labour market - need for a new approach. Journal of Human Resource Management, 20(2), str. 1-11.

30. Grossman, M., 1972. On the Concept of Health Capital and the Demand for Health. Journal of Political Economy, 80(2), str. 223-255.

31. Grossman, M., 2000. The human capital model. U: A. J. Culyer i J. P. Newhouse, ur. Handbook of Health Economics. Amsterdam: Elsevier.

32. Grossman, M., 2008. The Relationship Between Health and Schooling. Eastern Economic Journal, 34(3), str. 281-292.

33. Gustman, A. L. i Steinmeier, T. L., 2001. Retirement and Wealth. Social security bulletin, 64(2), str. 61-94.

34. Haveman, R., 2000. The economics of disability and disability policy. U: A. J. Culyer i J. P. Newhouse (ur.). Handbook of Health Economics. Amsterdam: Elsevier.

35. Idler, E. L. i Benyamini, Y., 1997. Self-Rated Health and Mortality: A Review of TwentySeven Community Studies. Journal of Health and Social Behavior, 38(1), str. 21. https://doi.org/10.2307/2955359

36. Jylhä, M., 2009. What is self-rated health and why does it predict mortality? Towards a unified conceptual model. Social Science \& Medicine, 69(3), str. 307-316. https://doi.org/10.1016/j.socscimed.2009.05.013

37. Kalwij, A. i Vermeulen, F., 2008. Health and labour force participation of older people in Europe: What do objective health indicators add to the analysis? Health Economics, 17(5), str. 619-638. https://doi.org/10.1002/hec.1285

38. Laplagne, P., Glover, M. i Shomos, A., 2007. Effects of Health and Education on Labour Force Participation. Melbourne: The Productivity Commission. https://doi.org/10.2139/ssrn.1018889

39. LaPlante, M. P., 2010. The Classic Measure of Disability in Activities of Daily Living Is Biased by Age but an Expanded IADL/ADL Measure Is Not. The Journals of Gerontology Series B: Psychological Sciences and Social Sciences, 65B(6), str. 720-732. https://doi.org/10.1093/geronb/gbp129

40. Leung, S. F. i Wong, C. T., 2002. Health status and labor supply: interrelationship and determinants. Hong Kong University of Science and Technology.

41. Lleras-Muney, A., 2005. The Relationship Between Education and Adult Mortality in the United States. Review of Economic Studies, (72), str. 189-221. https://doi.org/10.1111/00346527.00329

42. Malter, F. i Börsch-Supan, A., 2017. SHARE Wave 6: Panel innovations and collecting Dried Blood Spots. Munich: Munich Center for the Economics of Aging (MEA). 
43. Maurer, J., Klein, R. i Vella, F., 2011. Subjective Health Assessments and Active Labor Market Participation of Older Men: Evidence from a Semiparametric Binary Choice Model with Nonadditive Correlated Individual-specific Effects. Review of Economics and Statistics, 93(3), str. 764-774. https://doi.org/10.1162/rest_a_00097

44. Nuttall F. Q., 2015. Body Mass Index: Obesity, BMI, and Health: A Critical Review. Nutrition today, 50(3), str. 117-128. https://doi.org/10.1097/nt.0000000000000092

45. Ostrovidov Jakšić, A. i Jakšić, I., 2019. How to prolong labour market participation in the Republic of Croatia? Public Sector Economics, 43(1), str. 79-108. https://doi.org/10.3326/pse.43.1.6

46. Ozawa, M. N. i Lum, T. Y., 2005. Men Who Work at Age 70 or Older. Journal of Gerontological Social Work, 45(4), str. 41-63. https://doi.org/10.1300/j083v45n04_04

47. Reeuwijk, K. G. [i sur.], 2017. The influence of poor health on competing exit routes from paid employment among older workers in 11 European countries. Scandinavian Journal of Work, Environment \& Health, 43(1), str. 24-33. https://doi.org/10.5271/sjweh.3601

48. Rothman, K. J. i Greenland, S., 2005. Causation and causal inference in epidemiology. American Journal of Public Health, 95(S1), str. S144-S150. https://doi.org/10.2105/ajph.2004.059204

49. Sieminska, A. [i sur.], 2008. Patterns of motivations and ways of quitting smoking among Polish smokers: a questionnaire study. BMC Public Health, 8, str. 274. https://doi.org/10.1186/14712458-8-274

50. Spector, W. D. i Fleishman, J. A., 1998. Combining Activities of Daily Living with Instrumental Activities of Daily Living to Measure Functional Disability. The Journals of Gerontology Series B: Psychological Sciences and Social Sciences, 53B(1), str. S46-S57. https://doi.org/10.1093/geronb/53b.1.s46

51. StataCorp, 2017. Stata Statistical Software: Release 15. College Station, TX: StataCorp LLC: StataCorp. https://doi.org/10.7717/peerj.4598/supp-10

52. Tomić, I., 2014. Structural unemployment in Croatia - How important is the occupational mismatch? Economic Research-Ekonomska istraživanja, 27(1), str. 346-365. https://doi.org/10.1080/1331677x.2014.966969

53. Trevisan, E. i Zantomio, F., 2016. The impact of acute health shocks on the labour supply of older workers: Evidence from sixteen European countries. Labour Economics, 43, str. 171-185. https://doi.org/10.1016/j.labeco.2016.04.002

54. WHO, 2000. Obesity: Preventing and Managing the Global Epidemic. Geneva: WHO.

55. Zajacova, A. i Dowd, J. B., 2011. Reliability of Self-rated Health in US Adults. American Journal of Epidemiology, 174(8), str. 977-983. https://doi.org/10.1093/aje/kwr204 